\title{
The Influence of Indonesian Interest Rates, Inflation, Debt to Asset Ratio and Return on Asset against the Property and Real Estate Sector Stock Prices on the Indonesia Stock Exchange in 2014-2018
}

\author{
Yeni Ariesa $^{1}$, Agung Sahbana ${ }^{2}$, Prabowo Chuanda ${ }^{3}$, Cindy Angela Kirana ${ }^{4}$, Ervia \\ Florencia Livinda ${ }^{5}$, Wira Wijaya ${ }^{6}$ \\ 1,2,3,4,5.6 Faculty of Economics, Universitas Prima Indonesia \\ yeniariesa321@gmail.com,agungsahbana133321@gmail.com,Pchuanda@gmail.com, \\ cindyangelakirana@gmail.com, ervialie15@gmail.com,wirawijayaa28@gmail.com
}

\begin{abstract}
The aim of this study is to see the effect of Indonesia's interest rates, inflation, DAR and ROA on stock prices. This type of research is quantitative research, uses a deductive approach and is descriptive in nature. The population of the property and real estate sector has 52 companies, within 5 years, so the data totaled 155. The results of this study show that simultaneously SBI, inflation, DAR and ROA have a significant effect on stock prices. Partially, only ROA has a positive / significant effect on the stock price. Other variables, namely SBI, inflation and DAR do not affect the stock price. The amount of stock price variation that can be explained by the independent variable used is $18.3 \%$, the remaining $81.7 \%$ is influenced by other variables.
\end{abstract}

Keywords

SB; inflation; DAR ROA; stock prices

\section{Introduction}

Stock or stock exchanges are related to the sale and purchase of securities on the IDX or other names IDX. One form of trading on the IDX is the sale of shares. Stock prices often change according to the size of supply and demand. The demand for shares is influenced by a variety of information known to investors regarding the issuer, including information on the company's financial statements. Financial reports are a form of company management accountability to internal or external parties related to company performance in one period of time. What is in the financial statements, as an assessment of the company's shares for investors?

Among the various aspects that affect stock prices, namely Indonesian interest rates, inflation, DAR and Return on Asset. Below is an overview of property and real estate companies that shows a phenomenon in the research data. 
Table 1. Phenomenon of the Property and Real Estate Sector

\begin{tabular}{|c|c|c|c|c|c|c|}
\hline $\begin{array}{l}\text { Code } \\
\text { issuer }\end{array}$ & $\begin{array}{l}\text { Tribal } \\
\text { Year }\end{array}$ & $\begin{array}{l}\text { Flower } \\
(\%)\end{array}$ & $\begin{array}{l}\text { Inflation } \\
(\%)\end{array}$ & Debt & Net profit & $\begin{array}{l}\text { Price } \\
\text { Stock }\end{array}$ \\
\hline \multirow[t]{5}{*}{ ASRI } & 2014 & 7.75 & 8.36 & $10,553,173,020,000$ & $1,176,955,123,000$ & 560 \\
\hline & 2015 & 7.50 & 3.35 & $12,107,460,464,000$ & $684,287,753,000$ & 343 \\
\hline & 2016 & 4.75 & 3.02 & $12,998,285,601,000$ & $510,243,279,000$ & 352 \\
\hline & 2017 & 4.25 & 3.61 & $12,155,738,907,000$ & $1,385,189,177,000$ & 356 \\
\hline & 2018 & 6.00 & 3.13 & $11,339,568,456,000$ & $970,586,600,000$ & 312 \\
\hline \multirow[t]{5}{*}{ APLN } & 2014 & 7.75 & 8.36 & $14,223,273,846,000$ & $983,875,368,000$ & 335 \\
\hline & 2015 & 7.50 & 3.35 & $15,486,506,060,000$ & $1,116,763,447,000$ & 334 \\
\hline & 2016 & 4.75 & 3.02 & $15,741,190,673,000$ & $939,737,108,000$ & 210 \\
\hline & 2017 & 4.25 & 3.61 & $17,293,138,465,000$ & $1,882,581,400,000$ & 210 \\
\hline & 2018 & 6.00 & 3.13 & $17,376,276,425,000$ & $193,730,292,000$ & 152 \\
\hline \multirow[t]{5}{*}{ FATHER } & 2014 & 7.75 & 8.36 & $76,625,843,194$ & $7,046,505,797$ & 50 \\
\hline & 2015 & 7.50 & 3.35 & $74,812,450,750$ & $1,204,642,974$ & 50 \\
\hline & 2016 & 4.75 & 3.02 & $72,040,603,450$ & $1,818,062,130$ & 50 \\
\hline & 2017 & 4.25 & 3.61 & $58,885,428,727$ & $13,212,381,915$ & 88 \\
\hline & 2018 & 6.00 & 3.13 & $44,423,132,493$ & $4,950,263,483$ & 109 \\
\hline
\end{tabular}

Source: www.bi.go.id, financial reports of ASRI, APLN, BAPA

The explanation for this phenomenon is at PT. Alam Sutera Realty, Tbk Indonesia's interest rate in 2015 fell but stock prices fell, inflation in 2015 and 2018 fell, stock prices also fell, inflation in 2017 rose share prices also rose. Debt in 2016 went up, share price also went up, debt in 2018 went down, and share price also went down. 2016 net income decreased share price increased.

The phenomenon at PT. Agung Podomoro Land, Tbk Indonesia's interest rates in 2015 and 2016 fell, stock prices also fell, inflation in 2015, 2016 and 2018 fell, stock prices also fell, 2015 net income rose but stock prices fell. Income is the amount received usually within a certain period of time is usually one year, community income is thus all receipts received in a particular year either from industry, trade and other sectors. The economic condition of the population is a condition that describes human life that has economic score. Economic conditions are assessed through three variables: livelihoods, income, and ownership of valuables. (Shah et al, 2020).

Economic growth is still an important goal in a country's economy, especially for developing countries like Indonesia. Economic growth must also be followed by positive changes in the context of improving the welfare and prosperity of the people who are mandated by the 1945 Constitution. Therefore, economic development is still the focus of development in Indonesia and is an indication of the success of development. Economic growth is a process of increasing the production capacity of an economy that is realized in the form of an increase in national and regional income. (Magdalena and Suhatman 2020). While the phenomenon at PT. Bekasi Asri Pemula, Tbk inflation in 2018 increases, stock prices also go up, Indonesia's interest rates in 2017 increase, share prices also go up, 2018 net profit goes down, stock prices go up.

Based on the description and related phenomena, it is intended to conduct research with the title: " The Influence of Indonesian Interest Rates, Inflation, Debt to Asset Ratio and 
Return on Asset Against the Property and Real Estate Sector Stock Prices on the Indonesia Stock Exchange in 2014-2018 ".

\subsection{Formulation of the Problem}

The formulation of the problem in this study are:

1. How does the SBI interest rate affect the property and real estate sector share prices on the IDX for the 2014-2018 period?

2. How does inflation affect the property and real estate sector share prices on the IDX for the 2014-2018 period?

3. How does DAR affect the property and real estate sector share prices on the IDX for the 2014-2018 period?

4. How is the effect of ROA on the share price of the property and real estate sector on the IDX for the 2014-2018 period?

5. How do the SBI interest rates, inflation, DAR and ROA affect the property and real estate sector share prices on the IDX for the 2014-2018 period?

\section{Review of Literature}

\subsection{The Effect of SBI on Stock Prices}

According to Susanto (2015) if Bank Indonesia raises deposit rates, investors will take action by selling shares and switching to deposits which they feel are safer, so that if Indonesia's interest rates increase, investors will move their investments so that the stock price will decline.

According to Tandelilin (2010: 103) if the SBI increases, the stock price will decrease or vice versa. If the SBI increases, the return on investment related to interest rates, for example on deposits, will also increase. This situation can attract investors' interest, initially investing in stocks to transfer their capital in the form of deposits. So if more people release / sell their shares, the share price will decrease.

\subsection{Effect of Inflation on Stock Prices}

According to Susanto (2015), the impact of increasing inflation is that stock prices will decline due to an increase in the price of goods so that the purchasing power of investors will decrease.

According to Wira (2014: 17), a very high inflation rate will discourage investors because if BI suppresses inflation through raising interest rates, it will have an impact on falling stock prices.

\subsection{Cloudy Debt to Asset Ratio to Share Price}

According to Amrah and Elwisam (2018) a large debt ratio shows that if the company gets a large interest expense, the percentage of profits that its shareholders can receive is getting smaller. So investors are less interested in buying shares from the related company, which results in a decrease in demand and the company's share price.

According to Sitanggang (2015: 73), using a large amount of debt will increase the risk faced by shareholders and possibly the share price will decrease. 


\subsection{Cloudy Return on Asset to Share Price}

Amrah and Elwisam's opinion (2018) that the higher the ROA of a company, raises the confidence of investors to invest their capital, and increases investors' high expectations of dividend distribution which will then increase the demand for shares of related companies in the capital market.

According to Halim (2015: 23), stock price fluctuations are determined by the company's capacity to earn profits. If the profit tends to be large, it is very possible that the dividends paid tend to be large, then it will have a positive effect on the stock price on the stock exchange and investors will be interested in buying the shares. Thus the demand for shares will increase and the share price will increase.

\subsection{Previous Research}

Several previous studies that have examined the same are referred to by researchers namely:

1. Susanto (2015) entitled The Effect of Inflation, Interest and Exchange Rates on Stock Prices. The results show that partially inflation does not affect stock prices, interest rates and exchange rates have a significant effect on stock prices. Simultaneously, inflation, interest rates and exchange rates affect the stock price.

2. Valianti (2016), entitled The Effect of DAR, DER, ROA and NPM on Stock Prices in LQ45 Index Companies on the IDX. The results showed that DAR had a negative and significant effect on the stock price, ROA and NPM had a positive and significant impact on the stock price and DER did not affect the stock price. simultaneously DAR, DER, ROA and NPM affect the share price.

3. Rosana, et al (2017) entitled The Effect of Exchange Rates, Inflation, and Interest Rates on Stock Prices in Yang Companies Go Pub 1 ic on the IDX 2014-2016. The results showed that individually the exchange rate and inflation had a positive and significant impact on stock prices while interest rates had a negative and significant impact on stock prices. simultaneously the exchange rate, inflation and interest rates affect the share price.

\subsection{Conceptual Framework}

Below is a conceptual framework prepared, namely:

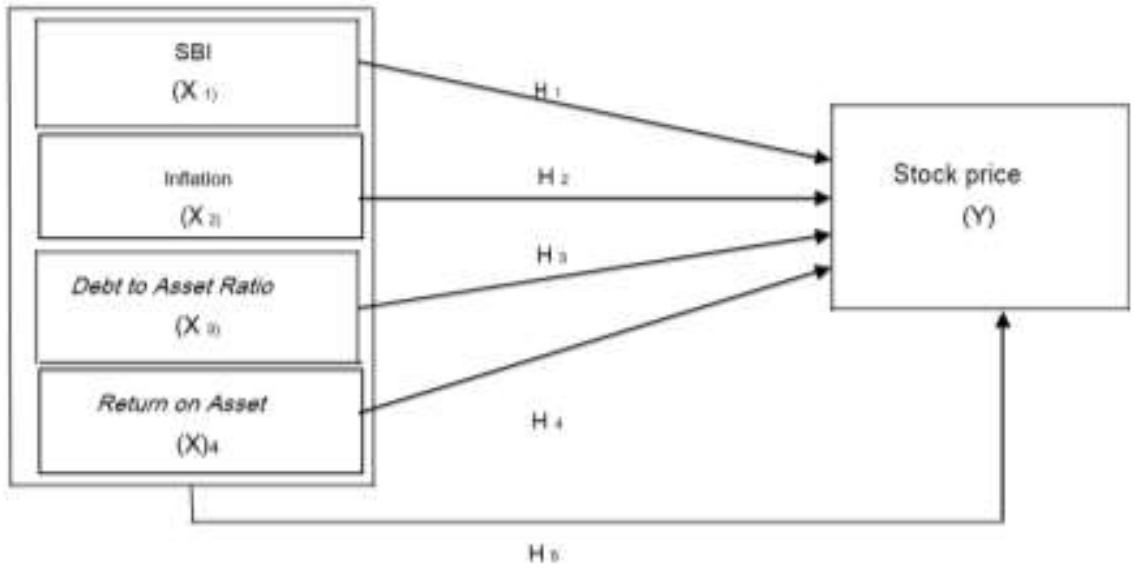

Figure 1. Conceptual framework 


\subsection{Research Hypothesis}

The hypothesis formulated by the researcher includes:

$\mathrm{H}_{1}$ : Indonesian interest rates partially affect the property and real estate sector stock prices on the IDX for the 2014-2018 period.

$\mathrm{H}_{2}$ : Inflation affects partially the share prices of the property and real estate sectors on the IDX for the 2014-2018 period.

$\mathrm{H}_{3}$ : DAR has an individual effect on the Property and Real Estate Sector Stock Prices on the IDX for the 2014-2018 period.

$\mathrm{H}_{4}$ : ROA has an individual effect on the Property and Real Estate Sector Stock Prices on the IDX for the 2014-2018 Period.

$\mathrm{H}_{5}$ : SBI interest rates, inflation, DAR and ROA affect the Property Sector Stock Prices and Real Estate on the IDX for the 2014-2018 period.

\section{Research Methods}

\subsection{Time and Place of Research}

The research will be carried out in property companies and Real Estate listed on the IDX and through the internet network, namely the official IDX website addressing the website www.idx.co.id, and lasts from March to December 2019.

\subsection{Research Methods}

This study applies a deductive approach, namely a general to specific presentation with quantitative data and descriptive explanations.

\subsection{Population and Sample Research}

Based on the 2018 Fact Book, the population was 52 companies. The research sample considerations are property companies and Real Estate listed on the IDX, issued a complete and sequential financial report during the 2014-2018 period and got the biggest profit in the 2014-2018 period.

Table 2. Sample Selection

\begin{tabular}{|l|l|c|}
\hline No. & \multicolumn{1}{|c|}{ Information } & Total \\
\cline { 2 - 3 } 1. & Company Property and Real Estate listed on the IDX & 52 \\
\hline 2. & not published complete financial reports sequentially in the 2014-2018 period & $(10)$ \\
\hline 3. & did not get a net profit in the 2014-2018 period the number of samples & $(11)$ \\
\hline & Number of samples & 31 \\
\hline & Number of periods & 5 \\
\hline & Number of Observations $=31 \times 5$ & 155 \\
\hline
\end{tabular}

\subsection{Data Collection Technique}

Before testing the data, first collect company financial report data downloaded on the IDX website and search for SBI and inflation data on the BI website.

\subsection{Types and Sources of Data}

The quantitative type of data sourced from other parties is also referred to as secondary data. 


\subsection{Identification and Definition of Operational Variables}

Operationalization makes it easier for researchers to provide an overview of what variables are used, namely.

Table 3. Operational Variables

\begin{tabular}{|c|c|c|c|}
\hline Variable & Definition & Indicator & Scale \\
\hline $\begin{array}{l}\text { Interest rate } \\
\text { SBI } \\
\text { (X1) }\end{array}$ & $\begin{array}{l}\text { Bank Indonesia Certificate is one of the } \\
\text { securities issued by Bank Indonesia in } \\
\text { recognition of short-term debt with a } \\
\text { discount / interest system } \\
\text { Source: Firdaus \& Ariyanti 2011: 101) }\end{array}$ & $\begin{array}{l}\text { SBI interest rates per } \\
\text { December 2014-December } \\
2018 \\
\text { Source: Bank Indonesia }\end{array}$ & Percent \\
\hline $\begin{array}{l}\text { Inflation } \\
\text { (X2) }\end{array}$ & $\begin{array}{l}\text { Inflation is defined as an increase in } \\
\text { commodity prices caused by the } \\
\text { unsynchronized program of the } \\
\text { commodity procurement system with the } \\
\text { level of income owned by the people in } \\
\text { a certain country. } \\
\text { Source: Putong (2013: 276) }\end{array}$ & $\begin{array}{l}\text { Inflation per December 2014- } \\
\text { December } 2018 \\
\text { Source: Bank Indonesia }\end{array}$ & Ratio \\
\hline $\begin{array}{l}\text { Debt to Asset } \\
\text { Ratio } \\
\text { (X3) }\end{array}$ & $\begin{array}{l}\text { DAR describes how much debt the } \\
\text { company has financed } \\
\text { Source: Valianti (2016) }\end{array}$ & $\begin{array}{l}\text { DAR }=\frac{\text { Total Debt }}{\text { total aset }} \\
\text { Source: Valianti }(2016)\end{array}$ & Ratio \\
\hline $\begin{array}{l}\text { Return on } \\
\text { Asset } \\
\text { (X4) }\end{array}$ & $\begin{array}{l}\text { It is the ratio of profit after tax to total } \\
\text { assets } \\
\text { Source: Ramdhani (2013) }\end{array}$ & $\begin{array}{l}\text { ROA }= \\
\text { net incame after tax } \\
\text { total assets } \\
\text { Source: Ramdhani (2013) }\end{array}$ & Ratio \\
\hline $\begin{array}{l}\text { Price } \\
\text { Stock } \\
(\mathrm{Y})\end{array}$ & $\begin{array}{l}\text { A reflection of the value of shares of } \\
\text { companies listed on the Indonesia Stock } \\
\text { Exchange } \\
\text { Source: Valianti (2016) }\end{array}$ & $\begin{array}{l}\text { End of year share price per } \\
\text { December 2014-2018 } \\
\text { Source: Darmadji and } \\
\text { Fakhruddin (2015: 157) }\end{array}$ & Ratio \\
\hline
\end{tabular}

\subsection{Classic Assumption Test}

The test is carried out before testing multiple regression. The prerequisite test to be tested is the normality test, multicollinearity, autoceralation and heterocedasticity.

\subsection{Research Data Analysis Model Multiple}

Linear Regression Analysis

The multiple regression formula used is:

$$
\mathrm{Y}=\mathrm{a}-\mathrm{b} 1 \mathrm{X} 1-\mathrm{b} 2 \mathrm{X} 2-\mathrm{b} 3 \mathrm{X} 3+\mathrm{b} 4 \mathrm{X} 4+\mathrm{e}
$$

With:

$$
\begin{aligned}
& \mathrm{Y} \quad=\text { Share Price } \\
& \text { A } \quad=\text { Constant } \\
& \text { b 1, b 2, b 3, b 4 = Regression coefficient } \\
& \text { X } 1 \quad=\text { Indonesian Interest Rate } \\
& \text { X } 2 \quad=\text { Inflation } \\
& \text { X } 3 \quad=\text { DAR } \\
& \text { X } \quad=\text { ROA } \\
& \text { e } \quad=\text { Standard error (error rate) }
\end{aligned}
$$




\subsection{Coefficient of Determination}

This test is often assumed by how much the ability of all variables to explain the variants of the dependent variable. The coefficient of determination is shown in value Adjusted R Square because the independent variable used 3 variables. (Ghozali, 2016: 95)

\section{a. F Test}

It aims to determine whether all the independent variables simultaneously affect the dependent variable. The $t$ test can be carried out by comparing the value of $F$ Count with the $\mathrm{F}$ table. If $\mathrm{F}$ count $>$ from $\mathrm{F}$ table, (Ho is rejected, $\mathrm{Ha}$ is accepted) and the opposite is if the value of $\mathrm{F}$ counts $<\mathrm{F}$ table (Ho is accepted, Ha is rejected). (Ghozali, 2016: 96)

\section{b. T Test}

Aimed at testing how the influence of each independent variable partially on the dependent variable. This test can be carried out by comparing the $t$ count with the table or by looking at the section of the significance column in each $t$ count column. The following criteria are used as a guideline for the $t$ test:

$\mathrm{H} 0$ accepted when $\mathrm{t}$ count $<\mathrm{t}$ table and significant $>0.05 \mathrm{H}$ a accepted when $\mathrm{t}$ count $>\mathrm{t}$ table and significant $<0.05$ (Ghozali, 2016: 97)

\section{Resultas and Discussion}

\subsection{Descriptive Statistics}

Companies that match the criteria to be the sample in this study amounted to 31 , so the total data amounted to 155 data. The following is an illustration of the minimum, maximum, mean and standard deviation of each variable:

Table 4. Descriptive statistics

\begin{tabular}{|l|r|r|r|r|r|}
\hline & $\mathrm{N}$ & \multicolumn{1}{|c|}{ Minimum } & \multicolumn{1}{c|}{ Maximum } & \multicolumn{1}{c|}{ Mean } & Std. Deviation \\
\hline Interest rate & 155 & 4.25 & 7.75 & 6,0500 & 1.41347 \\
Inflation & 155 & 3.02 & 8.36 & 4,2940 & 2,04963 \\
DAR & 155 &, 062 &, 787 &, 38779 &, 160081 \\
ROA & 155 &, 000 &, 359 &, 06295 &, 056817 \\
Stock price & 155 & 50 & 36500 & 2169.63 & 4757,502 \\
Valid N (listwise) & 155 & & & \\
\hline
\end{tabular}

The minimum value of the interest rate variable is 4.25 in 2016 while the maximum interest rate is 7.75 in 2014. The mean value of interest rates for the period 2014-2018 is 6.0500 and a standard deviation of 1.41347 .

The minimum value of the inflation variable is 3.02 in 2016, while the maximum value of inflation is 8.36 in 2014. The average value of inflation for 2014-2018 is 4.2940 and the standard deviation is 4.04963 .

The minimum value for the variable DAR value of 0.062 obtained by PT. Sitara Propertindo, Tbk in 2018 while the maximum value DAR 0.787 obtained by PT. Plaza Indonesia Realty in 2017. The average DAR value for 2014 - 2018 is 0.38779 and the standard deviation is 0.160081 .

Minimum value on the variable Return on Asset worth 0,000 obtained by PT. Gading Development in 2017 and PT. Pikko Land Development in 2018 while the maximum value of DAR was 0.359 obtained by PT Fortune Mate Indonesia in 2016. The value is mean DAR $2014-20180.06295$ and the standard deviation is 0.056817 . 
The minimum value of the Share Price variable is Rp. 50 which is obtained by PT. Bekasi Asri Pemula, period 2014 - 2016 and PT. Gading Development, Tbk in 2016, while the maximum value of the Share Price is Rp. 36,500, - obtained by PT. Metropolitan Kentjana, Tbk in 2017. The value of the average share price in $2014-2018$ is IDR 2,169.63 and a standard deviation of 4757,502 .

\subsection{Classic Assumption Test}

a. Normality

In testing the normality using 2 methods, namely graphical and statistical tests. The following are the results of the tests that have been carried out:

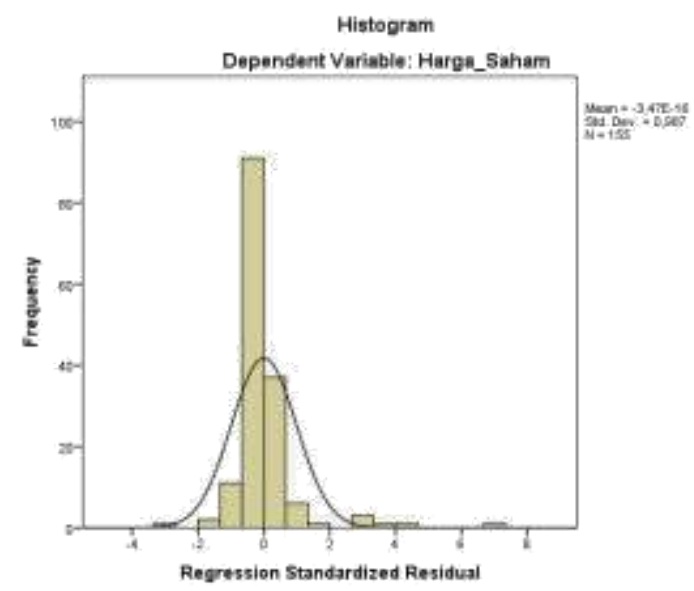

Figure 2. Histogram Normality Test Before Transformation

According to Figure 2 it can be seen that the research data is not normally distributed because the data is not symmetrical.

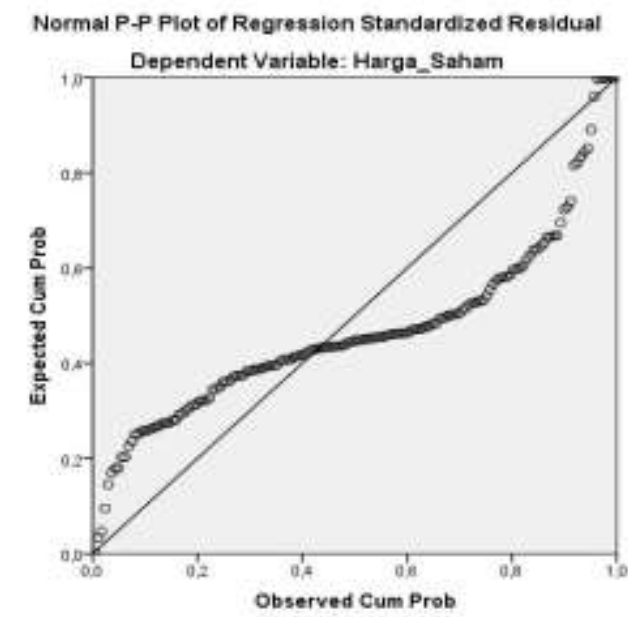

Figure 3. PP Plot Normality Test before Transformation

From Figure 3 it can be seen that the research data were not normally distributed because some of the data moved away from the diagonal line. 
Table 5. Kolmogorov Smirnov before Transformation One-Sample Kolmogorov-Smirnov Test

\begin{tabular}{|ll|c|}
\hline & & $\begin{array}{c}\text { Unstandardized } \\
\text { Residual }\end{array}$ \\
\hline $\mathrm{N}$ & Mean & 155 \\
Normal Parameters a, b & Std. Deviation & ,0000000 \\
& Absolute & 4351.05862678 \\
Most Extreme & Positive &, 220 \\
Differences & Negative &, 220 \\
Kolmogorov-Smirnov Z & &,- 171 \\
Asymp. Sig. (2-tailed) & & 2,739 \\
\hline
\end{tabular}

a. Test distribution is Normal.

b. Calculated from data.

The table shows that the research data is not normally distributed because the significance value is $>0.05$, while the significant value in the Kolmogorov Smirnov test shows a significance of $0.000<0.05$.

Good research data must meet the normality assumption so that the data in this study need to be transformed. The transformation technique used is LN. The test results after the data transformation were carried out, namely

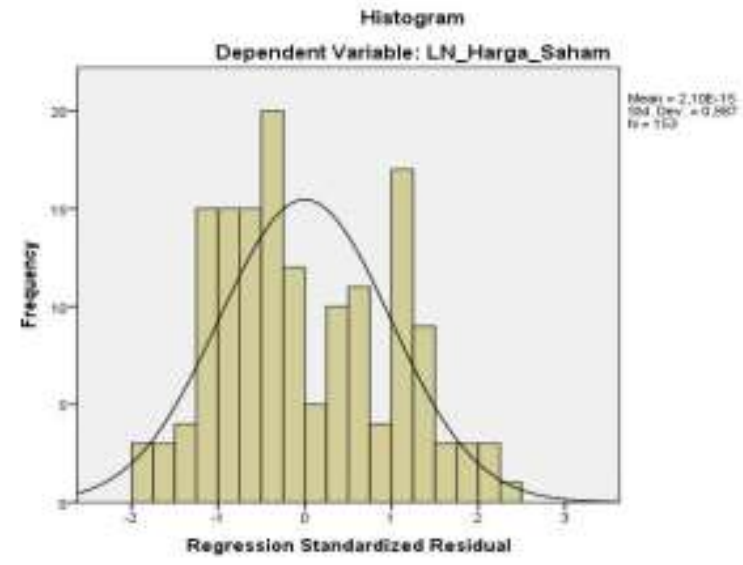

Figure 4. Histogram after Transformation

From Figure 4 it can be concluded that the data has been normally distributed because the research data tends to be symmetrical, but to find out whether the data is actually normally distributed it will be known from the P-Plot figure:

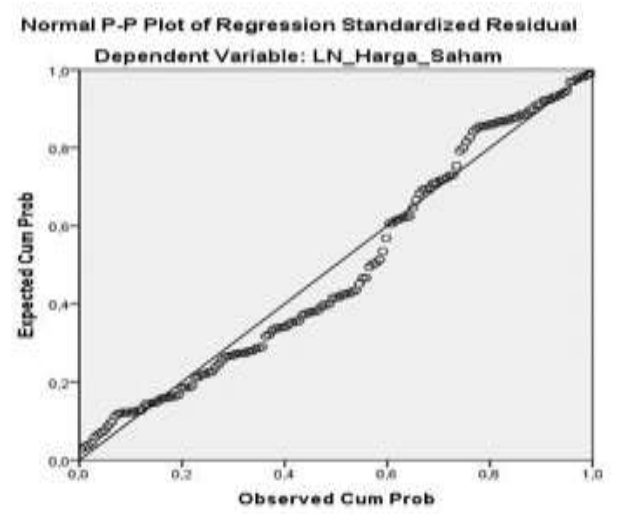

Figure 5. PP Plot after Transformation 
The image shows if the data is around the diagonal line so it can be concluded if the data is normally distributed.

Table 6. Kolmogorov Smirnov after Transformation One-Sample Kolmogorov-Smirnov Test

\begin{tabular}{|ll|r|}
\hline & & $\begin{array}{r}\text { Unstandardized } \\
\text { Residual }\end{array}$ \\
\hline $\mathrm{N}$ & Mean & 153 \\
Normal Parameters a, b & Std. Deviation &, 0000000 \\
& Absolute & 1.35549842 \\
& Positive &, 108 \\
Most Extreme Differences &, 108 \\
& Negative &,- 081 \\
Kolmogorov-Smirnov Z & & 1,334 \\
Asymp. Sig. (2-tailed) & &, 057 \\
\hline
\end{tabular}

a. Test distribution is Normal.

b. Calculated from data.

The table shows that if the significant value after the data is transformed into 0.057, where this value is $>0.05$, a conclusion can be given if the data is normally distributed

\section{b. Multicolinearity}

This test is a test of the second requirement after normality. To see whether there is no correlation between the independent variables, the tolerance and VIF values can be found.

Table 7. Multicollinearity before Transformation

Coefficients a

\begin{tabular}{|rl|r|r|}
\hline \multirow{2}{*}{ Model } & \multicolumn{2}{|c|}{ Collinearity Statistics } \\
\cline { 3 - 4 } & & Tolerance & \multicolumn{1}{c|}{ VIF } \\
\hline \multirow{3}{*}{1} & Interest rate &, 647 & 1,546 \\
& Inflation &, 650 & 1,539 \\
& &, 971 & 1,029 \\
& DAR &, 957 & 1,044 \\
\hline
\end{tabular}

a. Dependent Variable: Share_ Price

Table 8. Multicollinearity after Transformation

Coefficients a

\begin{tabular}{|rl|r|r|}
\hline \multirow{2}{*}{ Model } & \multicolumn{2}{|c|}{ Collinearity Statistics } \\
\cline { 3 - 4 } & & \multicolumn{1}{c|}{ Tolerance } & \multicolumn{1}{c|}{ VIF } \\
\hline \multirow{4}{*}{1} & LN_Suku_Bunga &, 699 & 1,432 \\
& LN_Inflation &, 691 & 1,447 \\
& LN_DAR &, 983 & 1,018 \\
& LN_ROA &, 971 & 1,030 \\
\hline
\end{tabular}

a. Dependent Variable: LN_Harga_Saham

The results of multicollinearity testing both before and after the transformation showed that the research data experienced meaningful multicollinearity in the absence

The relationship between the selected independent variables is because the overall variable tolerance value is $>0.10$ and the VIF value of all variables is $<10$. 


\section{c. Autocorrelation}

In time series research, an autocorrelation test is mandatory. The following are the results of the autocorrelation test both before and after data transformation:

Table 9. Autocorrelation before Transformation

Model Summary b

\begin{tabular}{|l|c|}
\hline Model & Durbin-Watson \\
\hline 1 & \\
\hline
\end{tabular}

a. Predictors: (Constant), ROA, Inflation, DAR, Interest_Rate

b. Dependent Variable: Share_ Price

By looking at the DW table guidelines; $\mathrm{k}=4$ and $\mathrm{n}=155$ then the value is:

$\mathrm{Dl}=1.68484-\mathrm{dl}=2.3152$

$\mathrm{Du}=1.79064-\mathrm{du}=2.2094$

So it can be concluded if the research data does not experience autocorrelation because the value of $\mathrm{du}<\mathrm{Dw}<4-\mathrm{du}$ or $1.7906<2.277<2.2094$

Table 10. Autocorrelation after Transformation

\begin{tabular}{|l|r|}
\hline \multicolumn{2}{|c}{ Test Runs } \\
\hline Test Value a & Unstandardized Residual \\
Cases <Test Value &,- 29014 \\
Cases> = Test Value Total & 76 \\
Cases & 77 \\
Number of Runs & 153 \\
Z & 86 \\
Asymp. Sig. (2-tailed) & 1,380 \\
\hline
\end{tabular}

From table 10 the autocorrelation test after transformation using the run test shows that the data does not experience autocorrelation because the significant value of the test results is $0.168>0.05$.

\section{d. Heteroscedasticity Test}

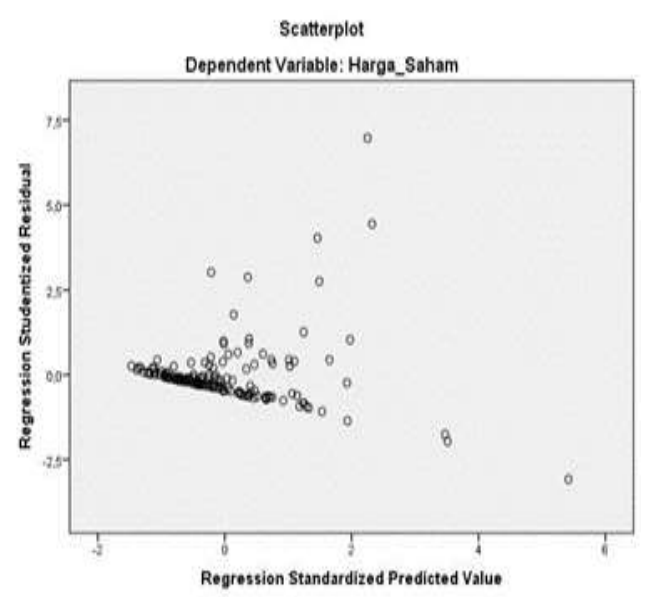

Figure 6. Scatterplot before Transformation 
From the results of the scatterplot graph test before the transformation, it can be seen that some of the data are clustered so that a conclusion can be made if the heteroscedasticity test results in this study a heteros problem.

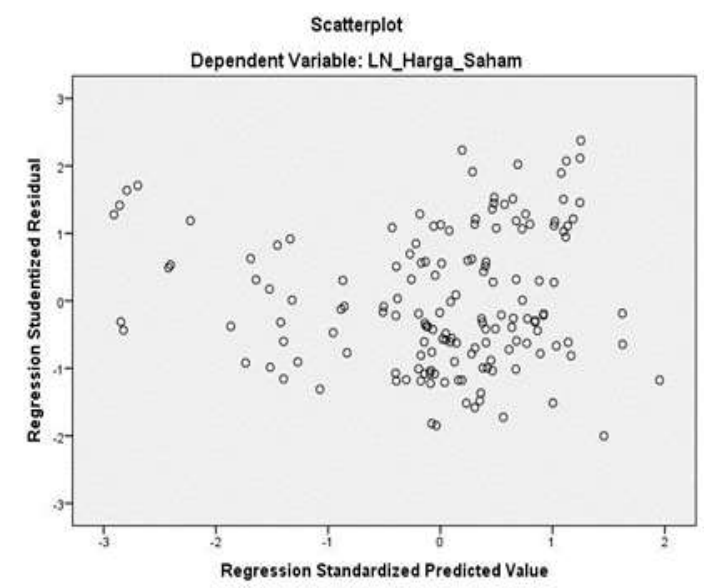

Figure 7. Scatterplot after Transformation

From the results of the scatterplot graph test, after the data transformation, it shows that the plot has been scattered randomly, but after the transformation of the scatterplot graph data it shows that the data is more randomly spread so that the data meets the prerequisite test requirements because it does not experience heteroscedasticity.

Table 11. Spearma's rho Heteroscedasticity Test before Transformation Correlations

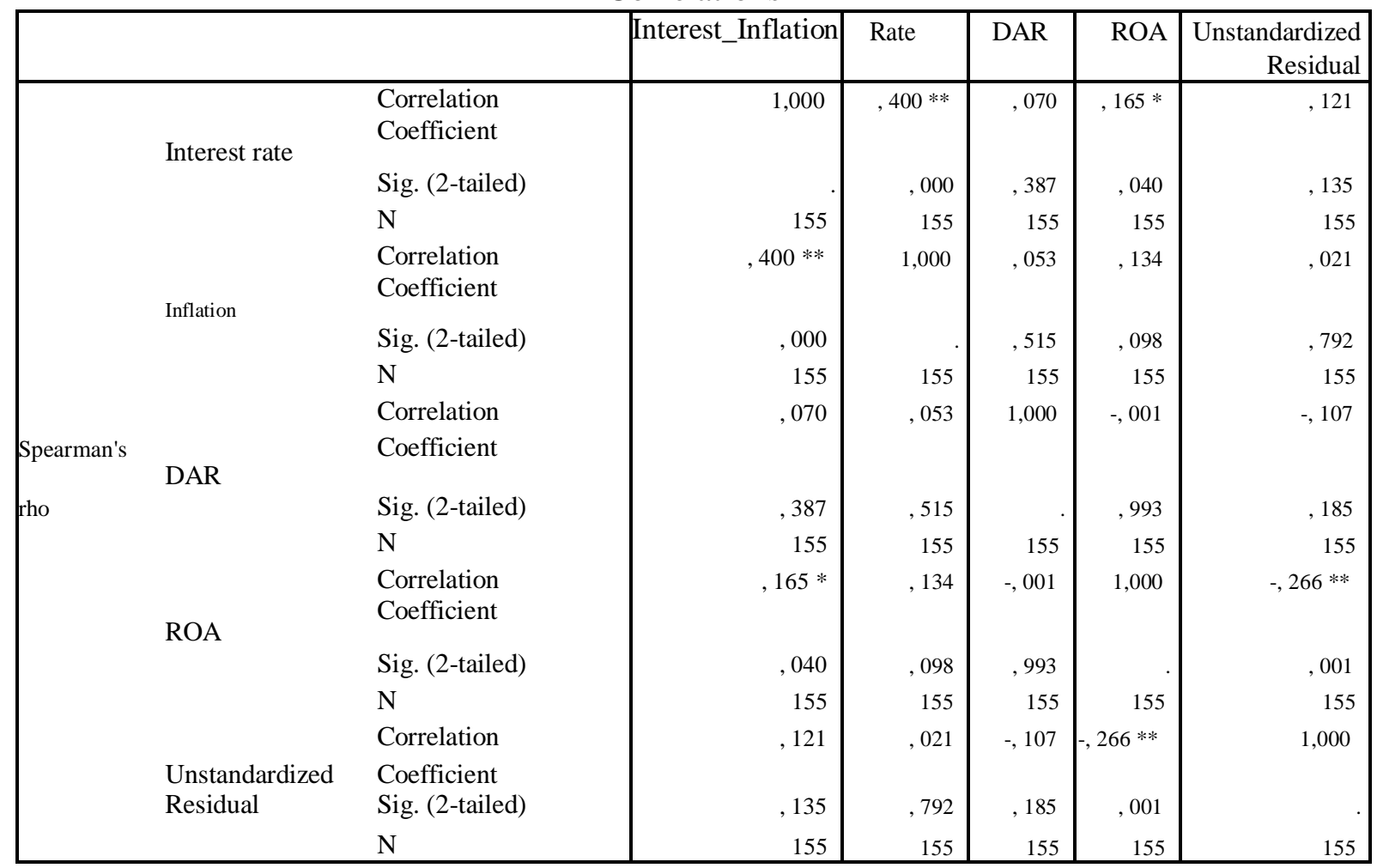

**. Correlation is significant at the 0.01 level (2-tailed).

*. Correlation is significant at the 0.05 level (2-tailed). 
The results of the Spearman's rho test before data transformation showed that the ROA variable had a significant value $<0.05$, so the results of this test experienced heteroscedasticity.

Table 12. Spearma's rho Heteroscedasticity Test after Transformation

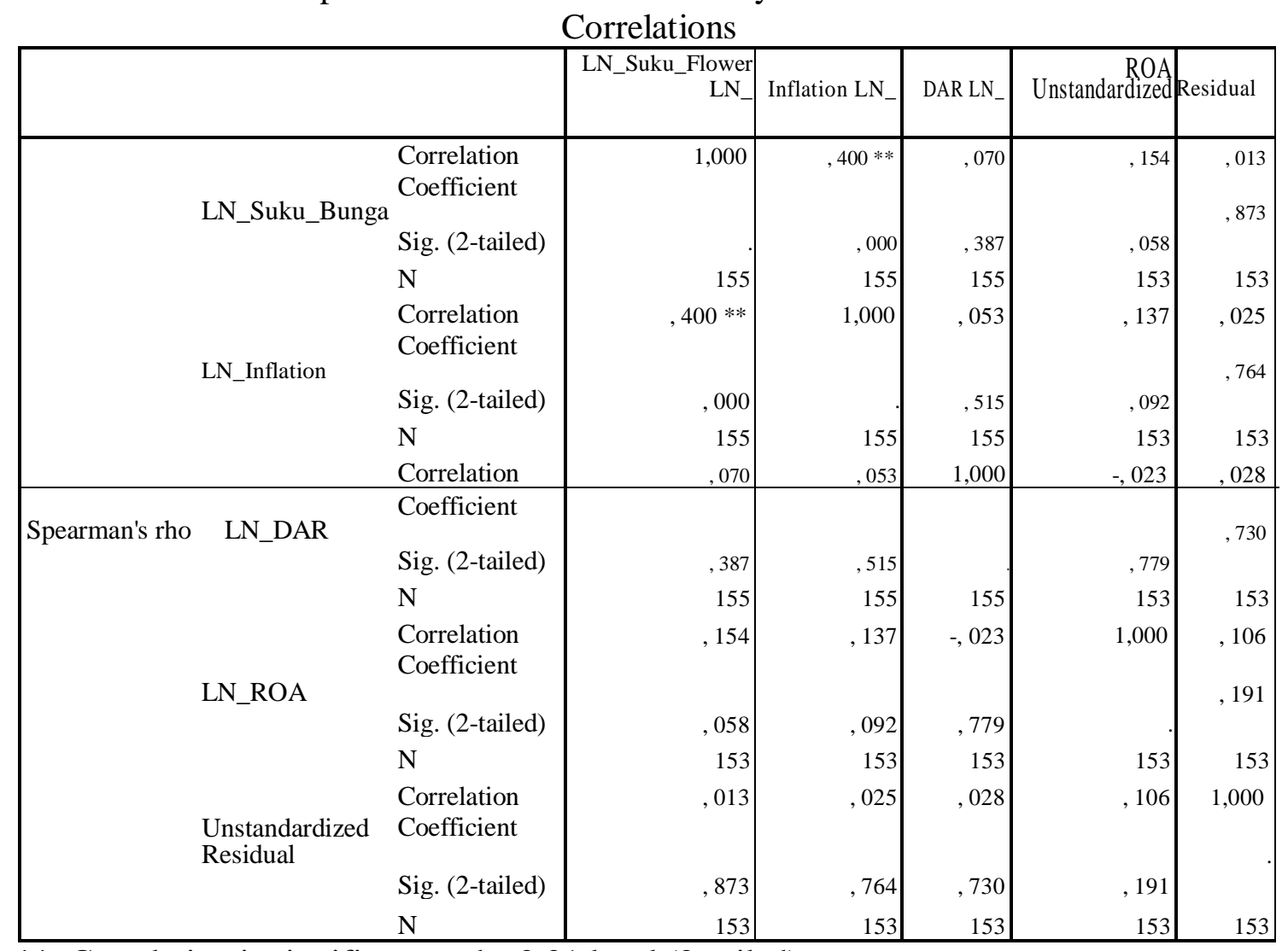

**. Correlation is significant at the 0.01 level (2-tailed).

The results of Spearman's rho praise after data transformation show that the data does not experience heteroscedasticity because the significant value of all independent variables is $>0.05$.

e. Hypothesis Test

Multiple linear regression

Table 13. Multiple Linear Regression Equation Coefficients a

\begin{tabular}{|c|c|c|c|c|c|c|}
\hline \multirow{2}{*}{\multicolumn{2}{|c|}{ Model }} & \multicolumn{2}{|c|}{$\begin{array}{r}\text { Unstandardized } \\
\text { Coefficients }\end{array}$} & \multirow{2}{*}{$\begin{array}{c}\begin{array}{c}\text { Standardized } \\
\text { Coefficients }\end{array} \\
\text { Beta } \\
\end{array}$} & \multirow[t]{2}{*}{$\mathrm{t}$} & \multirow[t]{2}{*}{ Sig. } \\
\hline & & B & Std. Error & & & \\
\hline \multirow{5}{*}{1} & (Constant) & 8,251 &, 934 & & 8,837 &, 000 \\
\hline & LN_Suku_Bunga &,- 038 &, 555 &,- 006 &,- 069 &, 945 \\
\hline & LN_Inflation &,- 027 &, 349 &,- 007 &,- 078 &, 938 \\
\hline & LN_DAR &,- 089 &, 208 &,- 032 &,- 427 &, 670 \\
\hline & LN_ROA &, 553 &, 090 & 457 & 6,138 &, 000 \\
\hline
\end{tabular}

a. Dependent Variable: LN_Harga_Saham 
From the test results in table 13, the following equation can be made:

LN_Shares Price $=8,251-0.038$ LN_Interest Rate -0.027 LN_Inflation - 0.089 LN_DAR + 0.553 LN_ROA

From the multiple regressions above, the following can be seen: The constant is 8.251 , which reveals that if:

1. Interest Rates, Inflation, DAR, and ROA constant value 0 so the share price is 8,251 units.

2. The Interest Rate Regression Coefficient of -0.038 reveals that if there is an increase in the Interest Rate of 1 , it will reduce the Stock Price by 0.038 units.

3. The inflation regression coefficient of -0.027 reveals that every 1 unit increase in inflation will reduce the Stock Price by 0.027 units.

4. The DAR coefficient of -0.089 reveals if any increases DAR 1 unit will lower the Share Price by 0.089 units.

5. Regression coefficient ROA 0.553 reveals that every 1 unit increase in ROA will increase the Stock Price by 0.553 units.

6. Regression coefficient Size 18,806 revealed if any increase occurred Size 1 unit will increase the stock price to 18,806 units.

\section{f. Coefficient of Determination}

Table 14. Determination Coefficient Test Model Summary

\begin{tabular}{l|c|c|c|c|}
\hline Model & $\mathrm{R}$ & $\mathrm{R}$ Square & $\begin{array}{l}\text { Adjusted R } \\
\text { Square }\end{array}$ & $\begin{array}{l}\text { Std. Error of } \\
\text { the Estimate }\end{array}$ \\
\hline 1 & \multicolumn{2}{|c}{, 205} & & 1,37369 \\
\hline
\end{tabular}
a. Predictors: (Constant), LN_ROA, LN_Suku_Bunga, LN_DAR,
LN_Inflasi

Based on table 14 it can be seen the magnitude of the influence of Interest Rates, Inflation, DAR, and ROA the share price in 2014 - 2018 was $18.3 \%$ while $81.7 \%$ was due to the influence of other variables.

\section{g. F Test}

Table 15. F test

ANOVA a

\begin{tabular}{|rl|r|r|r|r|r|}
\hline Model & & \multicolumn{1}{|c|}{ Sum of Squares } & df & Mean Square & F & Sig. \\
\hline \multirow{4}{*}{1} & Regression & 71,998 & 4 & 17,999 & 9,538 &, $000 \mathrm{~b}$ \\
& Residual & 279,281 & 148 & 1,887 & & \\
& Total & 351,279 & 152 & & & \\
\hline
\end{tabular}

a. Dependent Variable: LN_Harga_Saham

b. Predictors: (Constant), LN_ROA, LN_Suku_Bunga, LN_DAR, LN_Inflasi

In order to know whether the independent variable affects the dependent variable, the $\mathrm{F}$ count will be compared with the F table. By looking at the F table for df 1 (4) and df 2 (148), the $F$ table is 2.43 . So F count $(9,538)>F$ table 2.43 and the significance value $0.000<0.05$ means that simultaneously interest rates, inflation, DAR, and ROA significant effect on the share price. 
Table 16. $T$ test

Coefficients a

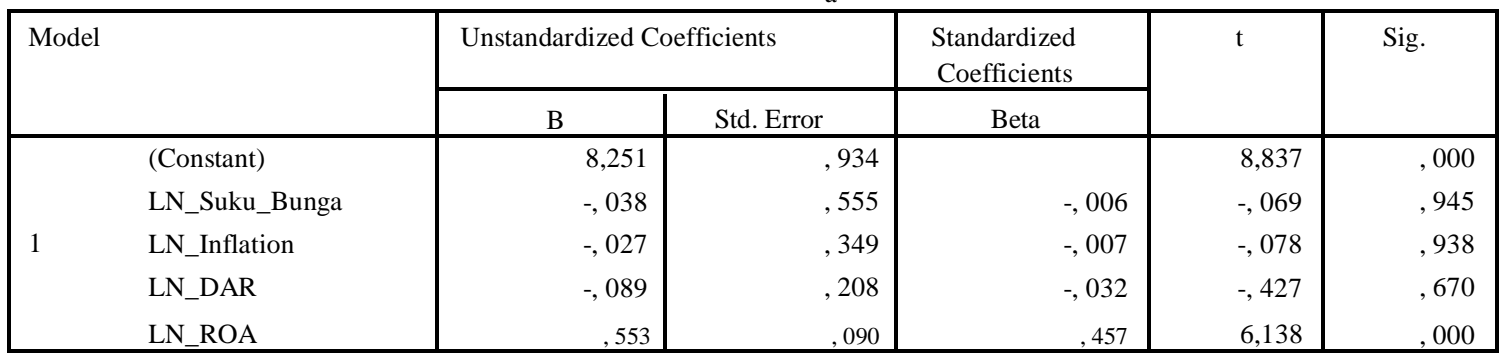

a. Dependent Variable: LN_Harga_Saham

The amount of $t$ table at 0.05 probability with a 2-way significance test level and df 148 is 1.97612. The following is an explanation of the $t$ test results:

1. Interest rates have a value of $-\mathrm{t}$ count $>-\mathrm{t}$ table or $-0.069>-1.97612$ and a significant value of $0.945>0.05$, it means that the interest rate has no effect on the share price.

2. Inflation has a value of $-\mathrm{t}$ count $>-\mathrm{t}$ table or $-0.078>-1.97612$ and a significant value of $0.938>0.05$, it means that inflation does not affect stock prices.

3. DAR has the value $-\mathrm{t}$ count $>-\mathrm{t}$ table or $-0.427>-1.97612$ with a significance of $0.010<$ 0.05 so that means DAR does not affect the Share Price.

4. Return on Asset has a value of $t$ count $>t$ table or 6.138> 1.97612 and a significant value of $0.000<0.05$, it means Return on Asset affect positively and significantly Price Stock.

\subsection{Discussion}

\section{a. Effect of Interest Rates on Y}

The results of the research prove that there is no effect on interest rates. The results of this study are also the same as those of Suriyani and Sudiartha (2018), namely that interest rates have no effect on stock prices.

The increase in interest rates does not affect investors' interest in moving their investment because investors are more interested in getting a higher return from their stock investment.

\section{b. Inflation Effect on Y}

The results of the research cannot show the influence of inflation on stock prices. The results of this study are also the same as the results of his research conducted by Susanto (2015), namely that inflation does not affect stock prices.

\section{c. Influence Debt to Asset Ratio against Y}

The results of the research prove that DAR has no effect on stock prices. The result of this research is also the same as that carried out by Priliyastuti and Stella (2017), namely that DAR does not affect stock prices.

\section{d. Influence Return on Asset against Y}

The results of the study showed a significant positive effect ROA at the Stock Price. The result of this research is also the same as that carried out by Damayanti and Valianti (2016), namely that ROA has a positive and significant effect on share prices. 
e. The Influence of SBI, Inflation, DAR, and Return on Asset against Y

The results of this research are simultaneously interest rates, inflation, DAR, and ROA has a significant effect on stock prices. As for the magnitude of the influence of Interest Rates, Inflation, DAR, and ROA the share price is $18.3 \%$ while the other $81.7 \%$ get the influence of other variables.

\section{Conclusion}

The research conclusions are:

1. Partially interest rates do not affect share prices in property and real estate companies listed on the IDX in 2014 - 2018

2. The results of the $t$ test on the Inflation variable do not affect share prices in property and real estate companies listed on the IDX in 2014 - 2018.

3. The results of the $t$ test on the DAR variable do not affect share prices in property and real estate companies listed on the IDX in 2014 - 2018.

4. The results of the $t$ test on the ROA variable have a positive and significant effect on share prices in property and real estate companies listed on the IDX in 2014 - 2018.

5. Simultaneously, interest rates, inflation, DAR, and ROA significantly influence stock prices. The magnitude of the influence of the independent variables on stock prices is $18.3 \%$, while the other variables are around $81.7 \%$.

Suggestions that are useful for interested parties, namely:

1. For the next researcher, suggestions are given to add variables such as CR, PBV and EPR and other variables so that they can get useful results for accounting, especially regarding stock investment.

2. Property and real estate companies are advised to take their financial performance more into account so that they are always within safe and good limits in the eyes of investors because poor financial performance will react to the declining share price.

\section{References}

Amrah, RY, \& Elwisam, E. (2019). Influence Current Ratio, Return On Assets, Debt To Equity

Ratio and Total Assets Turnover Against Stock Prices in LQ45 Companies 2013-2015. Scientific Journal of Management Science, 14 ( 1).

Firdaus, H. Rachmat and Maya Ariyanti. 2011. Commercial Bank Credit Management. Bandung: Alfabeta.

Ghozali, Imam. 2013. Multivariate Analysis Application with SPSS Program. IV mold, Semarang: Publisher BP-Diponegoro University.

Halim, Abdul. 2015. Investment Analysis in Financial Assets. Jakarta: Mitra Wacana Media.

Magdalena, S,. and Suhatman,, R. (2020). The Effect of Government Expenditures, Domestic Invesment, Foreign Invesment to the Economic Growth of Primary Sector in Central Kalimantan. Budapest International Research and Critics Institute-Journal (BIRCI-Journal). P. 1692-1703.

Priliyastuti, N., \& Stella, S. (2017). Influence Current Ratio, Debt To Asset, Debt To Equity,

Return On Assets and Price Earnings Ratio Against Share Price. Journal of Business and Accounting, 19 ( 1a-5), 320-324.

Putong, Iskandar. 2013. Introduction to Micro and Macro Economics. Jakarta: Mitra Wacana Media 
Ramdhani, R. (2013). The Effect of Return On Assets and Debt To Equity Ratio on Price

Shares in Financial Institutions on the Indonesian Stock Exchange. The Winners, 14 (1), 2941.

Rosana, R., Wahono, B., \& ABS, MK (2017). The Effect of Exchange Rates, Inflation, and Interest Rates

Against the Share Price of Yang Company Go public on the Indonesia Stock Exchange 20142016. Scientific Journal of Management Research, 6 (08).

Sitanggang, JP 2015. Advanced Corporate Financial Management. Jakarta: Mitra Wacana Media.

Shah, M,.M. et al. (2020). The Development Impact of PT. Medco E \& P Malaka on Economic Aspects in East Aceh Regency. Budapest International Research and Critics Institute-Journal (BIRCI-Journal). P. 276-286

Sugiyono. 2017. Qualitative and Quantitative Research Methods R \& D. Bandung: PT. Alfabeta.

Susanto, B. (2015). The Effect of Inflation, Interest and Exchange Rate on Stock Prices (Study

At: IDX Listed Property and Real Estate Sector Companies). Journal of ASET (Research Accounting), 7 (1), 29-38.

Suwarjeni, V. Wiratna. 2014. Complete Research Methodology, Practical and Easy to Understand. Yogyakarta: New Library Press.

Tandelilin, Eduardus. 2010. Portfolio and Investment Theory and Applications. First edition. Yogyakarta: Kanisius

Valianti, RM (2018). Effect of Debt To Assets Ratio, Debt To Equity Ratio, Return On Assets and Net Profit Margin Against Share Prices at LQ-45 Index Companies on the Indonesia Stock Exchange. Wahana Ekonomika Media Journal, 13 ( 1).

Wira, Desmond. 2014. Fundamental Analysis of Shares. Ed. 2, Excee 